\title{
From Exile to Nationalism: The Early Novels of George Lamming
}

Writing cannot forget the misfortune from which its necessity springs; nor can it count on tacit, rich, and fostering "evidences" that can provide for an "agrarian" speaker his intimacy with a mother tongue. Writing begins with an exodus.

-Michel de Certeau, The Writing of History

Caribbean festival arts still revolve around the aesthetic of assemblage. The makers of festival arts attach items both fabricated and found in the urban environment, and natural vegetation and animal materials, to superstructure in layers, resulting in a plethora of textures, colors, and collage-like forms.

-Judith Bettelheim et al., "Caribbean Festival Arts"

What I have identified as the essential feature of Caribbean modernism-the reversion of exile from a sense of loss into the necessity from which national consciousness springs-is limpidly presented in George Lamming's 1983 introduction to his first novel, In the Castle of My Skin, a work published soon after his arrival in England in 1953. In this introduction, which can be read as a commentary on the conditions in which Caribbean literature was produced in the 1950s, Lamming makes a basic linkage between exile (as the misfortune of the colonized writer) and the narrative of national liberation which arises to counter loss and displacement. Instead of tracing the origins of 
Caribbean narrative to an ahistorical and unproblematic aboriginal or ancestral source, or what de Certeau, in the epigraph above, calls "a mother tongue," Lamming argues that Caribbean narrative has developed in reaction to the pressures of the foreign language and culture imposed on it by the European colonizer. The resulting narrative techniques, analogous to what is identified as assemblage in my second epigraph, result from the superimposition of Caribbean forms on the colonial language and the tradition of the novel as a genre. ${ }^{1}$

Unlike the negritude generation, which had relied primarily on poetry to mediate their relationship with the colonizer and to secure their identity in the "given" language, Lamming and his circle were attracted to the novel because they believed that narrative offered a form and strategy for restoring the West Indian character to history. With his characteristic judiciousness, Lamming would later assert that after "the discovery" and the abolition of slavery, the third important event in Caribbean history was "the discovery of the novel by West Indians as a way of investigating and projecting the inner experiences of the West Indian community. ... The West Indian writer is the first to add a new dimension to writing about the West Indian community." 2 The novel, Lamming would add, had become the mediatory genre through which the region could be represented and the vehicle through which its repressed memories would be recollected. This relationship between narrative and history not only sets up a theme that runs through all of Lamming's writings; it also provides an ideological underpinning for his narrative strategies. As he puts it in his 1983 introduction to In the Castle of My Skin, "The novel has had a peculiar function in the Caribbean. The writer's preoccupation has been mainly with the poor; and fiction has served as a way of restoring these lives-this world of men and women from down below-to a proper order of attention; to make their reality the supreme concern of the total society" (p. xi).

Now, there was nothing unique in Lamming's desire to recenter the displaced Caribbean peasant in his narrative because, as he was quick to acknowledge, the subalterns, despite their long history of depriva-

1. See George Lamming, "Introduction," In the Castle of My Skin (New York: Schocken, 1983), p. xiv (further references are in the text); Michel de Certeau, The Writing of History, trans. Tom Conley (New York: Columbia University Press, 1988), p. 319; and Judith Bettelheim, John Nunley, and Barbara Bridges, "Caribbean Festival Arts: An Introduction," in Caribbean Festival Arts, ed. John Nunley and Judith Bettelheim (Seattle: University of Washington Press, 1988), p. 36 .

2. George Lamming, The Pleasures of Exile (London: Allison and Busby, 1984), p. 15. 
tion, represented "the womb" from which the West Indian writer had sprung and "the richest collective reservoir of experience on which the creative imagination could draw" (p. xi). Within the context of national consciousness and the formation of a Caribbean national culture, as numerous commentators have observed, it was imperative for Lamming to center the drama of history on the marginalized if he was to generate a narrative of liberation. Liberating narrative in the colonial situation, as Patrick Taylor has succinctly argued, sets out to disclose "the reality of human freedom in a particular historical form, the nation" and to transform the colony (the previous space of exile) into a new arena of national culture; and popular culture is imperative to this process. $^{3}$

However, Lamming's desire to transform the lived history of the Caribbean people into the unified drama of the nation faced several problems with an indissoluble impact on his narrative strategies, especially in the early novels. Simply put, when Caribbean novelists tried to use their narratives to activate the past, or to recenter the marginalized, they were confronted by a historical paradigm informed by both blockage and possibility. In Lamming's own words,

This world of men and women from down below is not simply poor. This world is black, and it has a long history at once vital and complex. It is vital because it constitutes the base of labor on which the entire Caribbean society has rested; and it is complex because Plantation Slave Society (the point at which the modern Caribbean began) conspired to smash its ancestral African culture, and to bring about a total alienation of man the source of labor from man the human person. [P. xi]

The result of this perverse modernization of the African was "a fractured consciousness," which raised fundamental problems of language and ideology. The Caribbean writer trying to represent this marginalized world and to turn it into the space in which nationalism might spring up would discover, in his own communities, a culture with an allegiance torn between "the imposed norms of White Power, represented by a small numerical minority, and the fragmented memory of the African masses: between White supremacy and Black imagination" (p. xi). In terms of values and ideological inclinations, then, the writer was confronted by a double retardation: on one hand, white

3. Patrick Taylor, The Narrative of Liberation: Perspectives on Afro-Caribbean Literature, Popular Culture, and Politics (Ithaca: Cornell University Press, 1989), p. 189. 
supremacy, by defining social status in terms of color, had inflicted psychological injury on the Africans; on the other hand, the blacks were ambiguous about "the credibility of their own spiritual history" (p. xi). If the writer was to turn to nationalism to fend off exile, if the affirmation of a community of language and culture was to be realized, Lamming had to negotiate, in narrative form, such gaps, chasms, and ambiguities, or even try to reconcile his community's divided loyalties. $^{4}$

Moreover, there is a sense in which Lamming, like many colonized writers of his generation, turned to writing as a way of dealing with certain fundamental anxieties about Caribbean nationalism and some apprehension about the colonized writer's ability to evoke a national consciousness from the fragments left behind by colonial rule. In other words, narratives on the emerging or anticipated Caribbean nation were motivated by the desire to counter disorder and fragmentation and to harmonize different racial, cultural, and linguistic entities into a national community. At the beginning of his career, Lamming sought to incorporate all the fragments and ambivalent value systems that defined the colony into a harmonizing narrative- "an imaginative record of the total society," he called it (p. xi). No sooner had this narrative desire been evoked, however, than it raised fundamental questions about representation, identity, exile, and nationalism:

Could the outlines of a national consciousness be charted and affirmed out of all this disparateness? And if that consciousness could be affirmed, what were its true ancestral roots, its authentic cultural base? The numerical superiority of the black mass could forge a political authority of their own making, and provide an alternative direction for the society. This was certainly possible. But this possibility was also the measure of its temporary failures. [Pp. xi-xii]

The "temporary failures" in this context are the betrayal of the working class revolt in several Caribbean islands in the 1930s, when popular movements were superseded by the colonial government's attempt to develop an alliance with the black middle class. ${ }^{5}$

4. Important background to this period can also be found in Rhonda Cobham, "The Background," in West Indian Literature, ed. Bruce King (London: Macmillan, 1979), p. 22; and Kenneth Ramchand, The West Indian Novel and Its Background (London: Heinemann, 1983).

5. After the labor unrest of the 1930s, which brought nationalism to the foreground of Caribbean politics, the 1940 s can be seen as an age of political compromise. Since the 1940s, notes Bridget Brereton, members of the emerging Caribbean elite in the French Antilles and the English-speaking territories have been "largely preoccupied with demonstrating their 


\section{WRITING IN LIMBO}

Immense problems thus faced the writer who tried to harmonize the disparate social elements of the colonial space into a national culture and to generate a narrative that would both articulate ancestral roots and provide an alternative direction for the emerging society. Lamming was one of the many Caribbean writers "who took flight from the failure" by going to exile in England in the early 1950s. But as we saw in the last chapter, the experience and ontology of exile would denaturalize the exiled writer's previous way of seeing and representing the colonial experience by straining, and ultimately debunking, the illusion of empire; to break through the consciousness that had imprisoned him in the dogma of the colonial mother, Lamming had to begin by redefining the terms that fixed him as a colonial subject. My intention in this chapter is to show how narrative figured prominently in this act of redefinition.

"Migration was not a word I would have used to describe what I was doing when I sailed with other West Indians to England in 1950," Lamming recalls. "We simply thought that we were going to an England which had been planted in our childhood consciousness as a heritage and place of welcome. . . England was not for us a country with classes and conflicts of interest like the islands we had left. It was the name of a responsibility whose origin may have coincided with the beginning of time" (p. xii). Even when he wrote and completed In the Castle of My Skin, now considered by many to be perhaps the most powerful narrative critique of the psychology of colonialism, Lamming had yet to develop a conceptual understanding of empire as "a very dirty word," one that bore any relationship "to those forms of domination we now call imperialist" (p. xii). In writing his first novel, within two years of his arrival in London, Lamming was still driven by contradictory instincts, he believes. On one hand, he was still subconsciously imprisoned "in that previous innocence which had socialized us into seeing our relations to empire as a commonwealth of mutual interests"; but, on the other hand, his experiences as a black person in the heart of the metropolis had convinced him that "there was never any such reciprocity of interests" and he needed to develop a new language for renaming his Caribbean reality (p. xiv). Ironically, though the childhood psyche was imprisoned in the fantasy of empire, it was to his childhood that Lamming would return to evoke the

command of European culture and their intellectual 'equality' with their metropolitan counterparts." See "Society and Culture in the Caribbean: The British and French West Indies, 18701980," in The Modern Caribbean, ed. Franklin W. Knight and Colin A. Palmer (Chapel Hill: University of North Carolina Press, 1989), p. 109. 
"tragic innocence" of his youth: "In the desolate, frozen heart of London, at the age of twenty three, I tried to reconstruct the world of my childhood and early adolescence. It was also the world of a whole Caribbean reality" (p. xii).

This shift from the realities of exile to the limitations and possibilities of the national space seems to support Edward Said's contention that "the interplay between nationalism and exile is like Hegel's dialectic of servant and master, oppositions informing and constituting each other. All nationalisms in their early stages develop from a condition of estrangement." 6 But how does a condition of estrangement engender narrative as the form that liberates the subject from the prisonhouse of colonialism? To answer this question, and to clarify the relationship between Lamming's exile and the narrative strategies he adopts in his early works, we need to read colonialism as something akin to what Said calls Orientalism - a form of discourse and an apparatus of knowledge whose powers of domination derive from the defeat of narrative by vision. Like Orientalism, the colonial vision derives its initial authority from its holistic view of the colonized, who are perceived not as actors in the narrative of history but in terms of fixed Eurocentric categories such as social Darwinism and "the nature of the Negro." According to Said, the systematic categories in which the colonized are entrapped assume that colonized subjects are both static and essentially transparent, but they cannot represent themselves. ${ }^{7}$

A notorious Caribbean example of this kind of discourse is James Anthony Froude's panoramic view of West Indian society, The English in the West Indies (1888). Although the famous English historian visited the West Indies for only a few weeks, he was confident enough to write a book extolling the power of England as the lord and master of her dominions and to negate any notion of self-government in the islands. The basic problem posed by Froude's work, as John Jacob Thomas stresses in Froudacity: West Indian Fables Explained (1889), was its disregard of even the elementary methodological integrity Froude would have insisted on if he were writing about a non-dominated society. ${ }^{8}$ This kind of "panoptic" discourse is, however, constantly under the pressure of history and the narrative by which history is

6. Edward Said, "Reflections on Exile," Granta 13 (Autumn 1984), 162.

7. Edward Said, Orientalism (New York: Vintage, 1979), p. 239.

8. For a discussion of Froude and Thomas, see Roberto Marquez, "Nationalism, Nation, and Ideology: Trends in the Emergence of a Caribbean Literature," in Knight and Palmer, The Modern Caribbean, pp. 306-8. 
represented. Because of its diachronic structure, observes Said, narrative sanctions temporal transformations, institutional change, and modernity-it introduces "an opposing point of view, perspective, consciousness to the unitary web of vision; it violates the serene Apollonian fictions asserted by vision." 9 Said's conception of narrative as diachronic form brings us to the conceptual question at the heart of Lamming's early works: why is it that works written in exile, presumably to counter displacement, are characterized by fragmentation and assemblage in both narrative style and language?

The need to counter the Apollonian fiction of empire seems to explain Lamming's desire to valorize the disruptive and diachronic functions of narrative. As he notes in regard to In the Castle of My Skin, he uses methods of narration in which things are never as tidy as critics would like: "There is often no discernible plot, no coherent line of events with a clear, causal connection" (p. x). Indeed, rather than appeal to a holistic world that might counter the loss and displacement discussed in the previous chapter, Lamming develops narrative strategies that underscore the converse process: his novels are primarily about a destabilized world of childhood and adolescence (In the Castle), of emigrants displaced in the place they hoped to claim through language and tradition (The Emigrants), and of the failure of the nationalist dream of a national culture that transcends race and class (Of Age and Innocence). Such persistent themes suggest that Lamming has accepted displacement as a strategic narrative possibility that allows the writer to deconstruct the colonial vision and to introduce the narrative of Caribbean history into the text. So although Lamming's early works are intended to evoke a narrative of decolonization and liberation, as several critics have argued, such a narrative is not possible until the writer has overcome the obstacles that block the realization of a national community of language and culture and of nationalism as a state of belonging. ${ }^{10}$ As a result, there is explicit tension between the author's desire for a grand narrative that will restore coherence to the Caribbean social body and the mechanisms of psychological blockage

9. Said, Orientalism, p. 248.

10. This issue and related questions are taken up in notable studies of Lamming including Sandra Pouchet Paquet, The Novels of George Lamming (London: Heinemann, 1982), pp. 1-12; Patrick Taylor, The Narrative of Liberation, pp. 187-90; Ian Munro, "George Lamming," in King, West Indian Literature, pp. 126-43; Selwyn R. Cudjoe, Resistance and Caribbean Literature (Athens: Ohio University Press, 1980), pp. 183-202; Ngugi wa Thiong'o (James Ngugi), Homecoming: Essays on African and Caribbean Literature, Culture, and Politics (Westport, Conn.: Lawrence Hill, 1972), pp. 110-44; Gloria Yarde, "George Lamming: The Historical Imagination," Literary HalfYearly 11 (July 1970), 35-45. 
generated by colonialism. If Lamming's early novels are motivated by the desire to "return a society to itself" — as he told graduating students at the University of the West Indies in 1980-then these narratives have had to seek a detour around the "hidden forms of censorship" in the dominant culture. ${ }^{11}$

The major criticism usually made against Lamming's novels is that the overt rhetoric the author evokes to express an anticolonial agenda never quite seems to find an appropriate narrative form, that there is always a gap between narrative desire and the strategies of representation the author adopts. For many influential critics of Caribbean literature, it often seems that Lamming cannot find an adequate mode of narration to carry out the linguistic and epistemological revolution to which his works are committed. ${ }^{12} \mathrm{My}$ contention, however, is that this gap between ideology and form is not a weakness; rather, the act of narration is an attempt to resolve ideological problems that predate writing itself, problems generated by the colonial situation. In effect, each of Lamming's works is marked by notable experimentation with narrative form-and form is defined in no unclear terms in The Pleasures of Exile as "a dialogue of conflicting methods about a commonly felt need." 13 In Lamming's early fictions, then, each "substance" seeks its "form," but the end result is usually heterogeneity in narrative stances and styles. In In the Castle of My Skin, a first person autobiographical method is often mixed with streams of consciousness; in The Emigrants internalized focalization is often broken by third person narration; and in Of Age and Innocence narration shifts from the third person to interior monologue and to the diary form.

In this chapter, I want to show how these shifts in narrative stance are dictated by the problems of representation which Lamming faces in his attempt to develop narrative strategies that will both assert the "commonly felt need" for decolonization and account for the conflicting impulses of colonial modernity. These problems include the need to recenter a black subject who has been constituted as an absence in colonialist discourse, the desire to construct a narrative practice that (by challenging the relationship between self and other) initiates a new episteme, and the impulse to accord the marginal writers and their versions of the metropolitan language authority in the context of the

11. Quoted by Pouchet Paquet, p. 4.

12. See, for example, Garth St Omer's review of Season of Adventure, Minnesota Review 19 (Fall 1982), 138.

13. Lamming, The Pleasures of Exile, p. 158. 
very institutions that repress that authority. An analysis of Lamming's early works helps us understand the precarious position of a previously marginalized Caribbean writer struggling to restore the narrative of his people's "spiritual" history using the language of the other.

Writing in the Tongue of the Other:

In the Castle of My Skin

In his 1983 introduction to In the Castle, Lamming has asserted-and many critics have been tempted to go along with him-that the method of narration in his first novel was conditioned by his concern with "the collective human substance of the Village" rather than any overt exploration of individual consciousness (p. x). ${ }^{14}$ Thus while other modernists of his generation would privilege the issue of selfhood as the locus of narration in a world in which individual consciousness seemed to be under siege, Lamming would go against the grain and privilege the communal and collective entity (or more appropriately the national space) as the key to his narrative strategies. Of his first novel, Lamming would claim that there was no "central individual consciousness where we focus attention, and through which we can be guided reliably by a logical succession of events. Instead there are several centers of attention which work simultaneously and acquire their coherence from the collective character of the Village" ( $p$. xi).

But this kind of retrospective reading is too neat: it is doubtful whether the character of the village is collective, given the class and racial divisions within it, and the absence of a coherent line of narration does not preclude causal connections. Similarly, the presence of "several centers of attention" in the novel does not diminish the important role the boy $\mathrm{G}$ plays both as a narrator and character in the novel. Clearly we cannot allow Lamming's narrative desire for a collective entity able to counter colonial fragmentation to conceal the problems he encounters the moment he tries to evoke a holistic AfroCaribbean universe in the womb of colonialism. On the contrary, if the

\footnotetext{
14. For example, Pouchet Paquet argues that the central figure in The Castle "crystallizes the experience of the entire community. In a sense he is the village; the history of his dislocation echoes the dislocation of the village. He is a collective character" (p. 4). While I concur with the first part of this assertion ( $G$ is certainly defined in relation to the changing history of the village), he is too subjective to be described as a "collective" character.
} 
goal of colonial power and its discourse is to negate the black self by smashing its ancestral African culture and alienating its labor, a cognizance of the problematic nature of selfhood is certainly an important prelude to writing. Lamming's basic premise that colonialism has engendered a fractured consciousness and an uncertainty of self in the Caribbean subject has important narrative implications in his first novel.

In a general discussion of the relationship between semiotics and cultural domination, Julia Kristeva makes a point that can help us understand the centrality of notions of selfhood in Lamming's novel. According to Kristeva, the writer's desire to establish a countervailing sign system demands "the identity of a speaking subject within a colonial framework, which he recognizes as a basis for that identity."15 Lamming cannot simply repress the individual consciousness, for doing so would affirm the will to power of a colonial discourse whose authority depends on the erasure of the colonial subject. Although Lamming may find that the generation of a reflexive subject within a colonial framework is a tortuous process, the act of narration is impossible without a subject-despite its "splitting" in language, such a subject and its struggle for a consciousness of self, community, and history are the key, if not the primary theme, of narration in The Castle. In this novel, narration appears to be predicated on an almost high modernist notion "of separation and abandonment, frustration and loss, and above all, of man's direct inner experience of something missing."16 But this modernist view of language and consciousness, which Lamming has borrowed from André Malraux, is not an end in itself; on the contrary, it is a prelude to situating the self in a larger community of meanings. The important point, though, is that for Lamming, there is no doubt that the colonial subject is defined by "the sense of a distance between the individual consciousness and a total reality as it impinges upon that consciousness, the conviction, as a fact of experience, of absence."17

And thus the narration of childhood, far from being the recovery of an "agrarian" ideal, becomes a return to the history that represses selfhood, an attempt to live up to the pressures of those references that

15. Julia Kristeva, Desire in Language, trans. Thomas Gora, Alice Jardine, and Leon S. Roudiez (New York: Columbia University Press, 1980), p. 18.

16. George Lamming, "The Negro Writer and His World," Caribbean Quarterly 5 (February 1958), p. 111.

17. Lamming, "The Negro Writer," p. 111. 
dislocate the self from the collective experience. At the beginning of the novel, as the boy reflects on the meaning of the rain that has fallen to spoil his ninth birthday, he initiates a narrative process that reveals the anxieties of selfhood and community surrounding the colonial subject. Instead of thinking about wish fulfillment and the happiness usually associated with a successful birthday, the boy is distracted by "the sodden grimness of an evening that waded through water," crevices on a wasted roof, and "the waterly waste" of his birthdate. If a birthday is the cultural code for the integrity of the self and the possibility of fulfilling desire, then Lamming's narrator has become a witness to a symbolic dissolution of his own selfhood: "It was my ninth celebration of the gift of life, my ninth celebration of the consistent lack of an occasion for celebration," he says (p. 9). The terms for narrating a genealogical moment have been reversed, the boy's place within a social framework that is disintegrating under the forces of nature is put into question, and his relationship to inherited meanings is subverted. Thus while the boy's mother reads the floods as "the showers of blessing and the eternal will of the water's source," he sees them as signifying death, decay, and destruction; they evoke the "image of those legendary waters which had once arisen to set a curse in the course of man" (pp. 9, 10).

So the inaugural moment of narration in The Castle is one of loss, a loss of identity and ontological bearings. In this novel, as in other major Caribbean texts such as Naipaul's A House for Mr. Biswas, beginnings are initiated by doubts about cultural references. Here, the boy looks at his village on the aftermath of the floods and sees "a marvel of small, heaped houses raised jauntily on groundsels of limestone. . . . Sometimes the roads disintegrated, the limestone slid back and the houses advanced across their boundaries to meet those on the opposite side in an embrace of board and shingle and cactus fence" (p. 10); the season of flood "could level the stature and even conceal the identity of the village" (p. 11). An important dialectic of self and community now develops: the narrator shifts his focus from his selfhood to his community and sees his lack of identity reflected in, and confirmed by, the structure of his village. In effect, the boy's most important mode of consciousness is negative-it is an awareness of collective loss which functions throughout the narrative as the sign of a haunting gap of memory and genealogy in his social construction. Rather than recalling and reorganizing past experiences, memory becomes a register of the narrator's most glaring absences: "And what 
did I remember? My father who had only fathered the idea of me had left me the sole liability of my mother who really fathered me. And beyond that my memory was a blank. It sank with its cargo of episodes like a crew preferring scuttle to the consequences of survival" (p. 11).

Because memory confronts him only with disabling conditions, the boy has substituted for it what he calls "inquiry" - preoccupation with the consequence rather than the causation of his crisis of identity. But any attempts to investigate family and communal history through narrative are bound to meet the issues of alienation, emigration, and exile discussed in the previous chapter. The boy cannot find ways of evading the long shadow of an absent father and, later in the narrative, the paternity represented by colonial authority. Thus he informs us, "My birth began with an almost total absence of family relations. My parents on almost all sides had been deposited in the bad or uncertain accounts of all my future relationships, and loneliness from which had subsequently grown the consolation of freedom was the legacy with which my first year opened" (p. 12). As a narrator, Lamming's subject finds he cannot anchor his story around tangible cultural references such as family, community, and history; his challenge is to turn the absences his memory uncovers into the subject of narration itself.

The boy's narrative is therefore about his failure to inherit his history and cultural tradition and about his search for alternative references. Lamming's conception of narration in a colonial situation is determined by the notion that a self that cannot be authorized by its history must invent itself and that this invention takes narrative forms. Language and narration open up the symbolic dimension, a world of possibilities in which the subject constitutes itself even when it cannot recover its identity. If the boy and his mother seem to invest much emotion in simple objects, such as pebbles and pumpkin vines (p. 16), it is because such objects have become important supplements for the self: the pebbles come to signify permanence and continuity in a world of shifting forms, while the vine is a symbol of organic growth in a world of fragmentation.

The problem of subjectivity in a colonial situation is, of course, complicated by the fact that the very institutions with which the self is supposed to identify-such as country, nation, and language-are antithetical to the narrator's interests and desires. In the circumstances, the colonial subject can only assert its repressed identity by using narrative as a means of countervailing the given or imposed 
cultural system. This process of countervailing, as Kristeva has noted in another context, forces the subject through "an unsettling, questionable process" which coincides with "times of abrupt changes, renewal, or revolution in society." 18 For Lamming, however, the countervailing gesture is preceded by a critical reflection on the dominant social framework. In The Castle, what is crucial to the act of narration is not the challenge the colonial subject poses to the colonial economy of meanings, but the strategies characters develop either to understand the colonial situation or to retreat from it. For example, in the context of the colonial school-which is, significantly, constructed on the model of a slave ship (p. 36) —the boys are educated in the ways of imperialism and empire, while slavery, the basic fact of their history and existence, is concealed from them, is indeed erased from the existing episteme. Narration becomes a process of developing a critical attitude toward what I have already called the colonial vision.

During the school parade, the schoolboys read the flags that signify British colonialism in the Caribbean as fetishes: "They understood the flags. They understood them because they did not need to question them. The flags explained their presence, and the parade and the inspector. All these things were simple. They simply were" (p. 56). In contrast, the experience of slavery, which dominates the repressed consciousness of the island (some of the old people in the village were actually born slaves), is denied significance and the power of reference: "It had nothing to do with the people of Barbados. No one there was ever a slave, the teacher said. It was in another part of the world that those things happened" (p. 57). In their search for methods of narrating the unspoken and invisible, the boys try to go beyond the realities imposed on them by the colonial system and its language.

But although Lamming's characters attempt to develop a reflective understanding of their formation as colonized people as a prelude to negating the colonial situation, their utterances are often fixed at the originating source of the myth of empire. Self-engenderment is therefore dependent on questions of colonial beginnings and their implications. For example, if William the Conqueror was closer to the colonial subjects than their ancestral experience of slavery-as the textbooks and the teachers claim - and if the institutions that actually shaped the island's history are too far back to be taught as history, what is history and where does it begin? The schoolboys, we are told, "had read about

18. Kristeva, p. 18. 
the Battle of Hastings and William the Conqueror. That happened so many hundred years ago. And slavery was thousands of years before that. It was too far back for anyone to worry about teaching it as history" (p. 58). The function of colonial history as a self-serving fabrication is apparent here: the Battle of Hastings is brought closer in time (so that it can function as history) while the experience of slavery (less than a hundred years old in actuality) is banished from time and memory. For the colonial school, the event that launches the Caribbean's perverse modernity is left in temporal suspense and then condemned to silence. Represented by the teacher as prehistory- "History had to begin somewhere, but not so far back" (p. 58)-slavery is effectively demodernized and deprived of its constitutive powers.

But in the process of reflecting on the meaning of slavery, which has been mentioned almost casually by an old woman, the boys begin the important step of seeking an alternative narrative of history. As a starting point, they discover that it is difficult to recover reality (an original experience) from the colonial text; they now know that to theorize about their context, which is defined by fetishized signs such as coins and flags, is an important step to a new, ironic relationship with hegemonic notions of colony and empire. For even as the school asserts the special relationship between England and Barbados, the boys are surrounded by signs of crisis, signs that challenge this illusionary construct of "Little England." In fact, outside the context of the colonial school-around Savory's cart, for instance-the boys discover a new community of language in which speech is no longer formalized in signs and clichés about affairs that are remote and unreal. Here language displays what Lamming considers to be its "mischievous powers." 19 Around Savory's cart, language expresses its will to power through speech: "Talk was humorous, censorious and often filled with gossip. Sometimes someone had read or heard about something published in the paper and would break the news to the others. Things were going from bad to worse, they would agree, and suddenly their talk was filled with a kind of manufactured indignation" (p. 92). In this world of orality, the colonial subject has the possibility of breaking through the formalities of the colonial vision in two ways: first, in its mastery of "talk," the subject is subconsciously linked to African traditions and thus reconnected to the culture and genealogy which the colonial school represses; second, the oral world is not

19. Lamming, "The Negro Writer," p. 109. 
subjected to the linguistic censorship that retards the boys' quest for meanings in the colonial school.

Outside local scenes such as Savory's cart, however, the oral culture is not recognized as a source of authority; thus Lamming's characters often have to struggle to master formalized language and find ways of breaking through the veil of codified speech which surrounds their lives. In many cases, these subjects find it difficult to be fluent in the dominant language; many of them suffer from a stammer, here posited as a symptom of the uncertainty of self which compels some of them to seek solace and security in the colonial arrangement. For example, the boy Trumper speaks with confidence about his feelings, but he is often haunted by what he considers to be his linguistic retardation-he finds it difficult to say what he means "without knowing the right words" (p. 143). Because they have not mastered the duplicitous language of self-alienation which some of the adults use, the boys cannot represent themselves except by externalizing their desires, projecting their needs onto powerful figures such as their teachers, who seem to have been authorized to speak because of their cozy relationship with the colonizer. Often, the boys will hang onto any figure who seems to provide an alternative form of authority of action and language.

Consider, for example, the famous scene in the novel in which the boys encounter a fisherman on the beach and reflect about the meaning of his authority: "There was someone powerful and corrective about his figure," they immediately conclude (p. 148). Corrective in what sense? As a model to be adopted? As a stand-in for the absent male authority figures in the community? At this point in the novel, what the fisherman represents is not clear to the boys because he strikes mixed emotions in them: "We had a feeling of release and frustration when he went. We were glad to be without him there looking round, and not sure what he might say if he saw us" (p. 149). But as a spectacle, as a mirror image that expresses the boys' ambivalent posture - their desire for authority and their fear of control-the fisherman is both inviting and threatening, something to be identified with and, at the same time, to be feared.

In addition, the fisherman appears to the boys as an autonomous entity in a social situation in which adults often appear hopelessly dependent and compromised. This point becomes more poignant if we recall that before they meet the fisherman, the boys have witnessed the principal of their school kowtowing to the white inspector 
of schools (p. 39). The fisherman hence seems to project the kind of power and authority which is self-engendered, that is, not derived from the colonizer. For this reason, the boys would like to be recognized by him, or to place him at the center of the alternative value system they often imagine once they are out of school. When the fisherman contemptuously fishes Boy Blue from the sea, the boys see this authority figure as someone they can identify with; he is not as remote and dehumanized as their school principal: "He was only big and strong, as we would say in the village, but he was like one of us, just like one of us. A man" (p. 153). The encounter between the boys and the fisherman becomes epiphanic.

Interestingly enough, what the boys are seeking - and this is Lamming's narrative quest too-is a semiotic space and a form of linguistic practice in which self, language, and desire can be represented without being mediated by the colonizer. Although the boys are alienated by the colonial language of their education and socialization, they have come to believe that mastering this language is their only hope of overcoming marginalization. Therefore they lament the fact that although they can "talk and talk and talk" among themselves, they cannot "tell anybody what we had talked about. People who were sure of what they were saying and who had the right words to use could do that" (p. 153). "Language was a kind of passport," they are told, which can even compensate for feelings-"You had language, good, big words to make up for what you didn't feel" (p. 154).

This dependency on the language of the other is the primary source of what Lamming deems to be the tragic nature of colonial subjects. This language hampers the subjects' willed entry into history because instead of asserting the individual's coming to consciousness, it signalizes the distance between "the individual consciousness and a total reality as it impinges that consciousness"; instead of being the symbolic manifestation of "the fact of experience," language triggers the "dislocation of facts . . . and meanings." 20 Although the momentum for narration in The Castle arises from the narrator's attempt to recover the voice and memory of Afro-Caribbean people, an ancestral voice that is ultimately expressed in Pa's dreams, Lamming's indebtedness to high modernism is revealed in his conception of language as the thing that frees and imprisons at the same time. As one of the boys

20. Lamming, "The Negro Writer," p. 111. 
notes, language cuts both ways: "You could slaughter your feelings as you slaughtered a pig. Language was all you needed. It was like a knife" (p. 154).

Moreover, Lamming is conscious of the ways in which the colonial language affects perception and self-knowledge. In its transitive function, language is conditioned and extended by the consciousness it seeks to express: the writer seeks to seize the world and give it form through language, but a writer does not only use language- "he helps to make language." 21 It is in this conception of language that Lamming appears closest to the high modernist views of literary expression popular when he first wrote his novel. In this tradition, as Alan Wilde has noted in a critical discussion of late modernist poetics, language is not seen as "a means of discovering or evoking some final and ultimate 'Truth,' but as a way of releasing the self and of thereby making the phenomenal world once more the scene of purposeful action-the site, even, of the New Country." 22 Indeed, a central concern in The Castle is how the colonized self can be released from the language that blocks self-expression while using that language to evoke a "New Country."

There are several examples of how the transitive and phenomenological functions of language affect narration in Lamming's novel, especially in the strategies his characters develop to deal with their linguistic stammers and impasses. The first example is provided by the boy $\mathrm{G}$, who as he grows older finds it difficult to account for his own feelings or to represent himself without mediators. He therefore seeks to project his desires onto objects: "I didn't know myself what my intentions were, but this feeling, no longer new, had grown on me like a sickness. I couldn't bear the thought of seeing things for the last time. It was like imagining the end of my life" (p. 213). The boy selects a pebble onto which he projects his unrepresentable desires; in a drastic reversal of common notions of subjectivity, the narrator seems to believe that the integrity of the self is better preserved through objectification; by investing itself in the pebble- "I knew it, shape, size and texture" (p. 213) - the self can come into touch with its desires, and hence reflect its feelings. Such is the value of this selfhood invested in an object that when $G$ loses the pebble, he sees this loss as a sign of "the other's interference": "There was nothing I could do but

21. Lamming, "The Negro Writer," p. 113.

22. Alan Wilde, Horizons of Assent: Modernism, Postmodernism, and the Ironic Imagination (Baltimore: Johns Hopkins University Press, 1981), p. 99. 
carry the feeling of the other's interference and resign myself to the loss" (p. 214). The loss of the pebble also foretells anotherdimension of alienation: when $\mathrm{G}$ goes to the high school, he is finally detached from his childhood friends and from the village by the very education that was supposed to lead to self-realization. ${ }^{23}$

Posited as the very mark of modernity - that is, as the entry point to the world of the other-the school is mistakenly assumed to be the vehicle for mastering the self and its language. As G's mother says, "The mind was the man ... and if you had a mind you could be what you wanted to be and not what the world would have you" (p. 220). But this notion of mastery is undermined significantly when we realize that the modernizing power of the school marks the apotheosis of the colonial subject's socialization away from its ancestral sources. G comments: "I remained in the village, living, it seemed, on the circumference of two worlds. It was as though my roots had been snapped from the centre of what I knew best, while I remained impotent to wrest what my fortunes had forced me into" (p. 220). But the subject has no choice but to adopt this alienation and turn it into a positive value; rather than seek recognition from either the village or the colonizer, the self strives to maintain its integrity by masking itself: "I am always feeling terrified of being known; not because they really know you, but simply because their claim to this knowledge is a concealed attempt to destroy you. That is what knowing means" (p. 261). As I noted in the last chapter, this form of masking necessitates withdrawal from the world-a state of exile which is an important prelude to writing about the self.

An alternative response to the crisis of identity and representation in the island is presented by Trumper. After a restless and futile attempt to understand what is taking place in the community, Trumper has migrated to the United States, but at the point of G's departure for Trinidad he has returned home on a visit. The American experience has changed the boy who used to have problems expressing himself: "Trumper was smiling. A big, confident, self-assured smile. His assurance puzzled me" (p. 281). Above all, Trumper's stammer has diminished: "His voice was deeper, and he spoke more slowly and

23. For critical discussions of the themes of alienation and colonialism in Lamming's works, see Ambroise Kom, "In the Castle of My Skin: George Lamming and the Colonial Caribbean," World Literature Written in English 18 (November 1979), 406-20; Ian Munro, "The Theme of Exile in George Lamming's In the Castle of My Skin," English Literature Written in English 20 (November 1971), 51-60; Eugenia Collier, "Dimensions of Alienation in Two Black American and Caribbean Novels," Phylon 43 (1982), 46-56. 
with greater care" (p. 281). His feelings about the land, and his relationship to the landscape, are now expressed directly, no longer mediated by the other, no longer confused by divided loyalties. What has brought about this transformation? In the United States, to use Lamming's apt phrase, this black man "was forced to recognize himself as a different kind of creature" and to adopt his difference as the source of a new national identity (p. xv). In effect, Trumper is able to make the epistemological breakthrough that has eluded other characters, including the head teacher and Mr. Slime, by recognizing the difference between self and other and by stressing the differences (self/other, slave/master) which the colonial institution tried to repress through the myth of empire.

Furthermore, although Trumper recognizes the tension between the colonial self and its language, he has found ways in which this language can be nationalized, as it were. Toward this end, he deconstructs the phenomenon of language itself; he shows that language is not a natural entity that expresses a spontaneous experience, but a fabrication; if language has been fabricated to repress the identity and historicity of the colonized, it can also be used as the agent of a black narrative. So in trying to develop a discourse on race, which was previously a taboo in the Caribbean where official colonial discourse represented black people as appendages of the British colonial tradition, Trumper reflects on the differences between the words Negro and nigger in the United States and the Caribbean. When G wonders "What's the difference?" Trumper provides an answer that indicates the extent to which alienation and self-doubt have given way to national pride:

\footnotetext{
"'Tis a tremendous difference," said Trumper. "One single word make a tremendous difference, that's why you can never be sure what a word will do. ... It make a tremendous difference not to the whites but the blacks. 'Tis the blacks who get affected by leavin' out that word 'man' or 'people.' That's how we learn the race. 'Tis what a word can do." [P. 297]
}

For Trumper, these new terms-Negro, my people, and race-have opened a new space of resistance and identity which, at the same time, forces the narrator, confronted by the inadequacy of his education and language, to be suspended in silence: "I had nothing to say because I wasn't prepared for what had happened. Trumper made his own experience, the discovery of a race, a people, seem like a revelation. It 
was nothing I had known, and it didn't seem I could know it till I had lived it" (p. 298). Earlier in the novel Trumper is represented as a boy incapable of either acquiring fluency in the language of the other or entering the narrative of history; at the end of the novel, he is the agent of historical transformation: "He knew the race and he knew his people and he knew what that knowledge meant" (p. 298).

But if Trumper has mastered his life through understanding (according to the narrator, "He had found what he needed and there were no more problems to be worked out. Henceforth his life would be straight, even, uncomplicated" [p. 298]), this form of mastery is not endorsed by the narrator. In fact, the nationalism that develops out of Trumper's American experience is shown to be both insightful and limited: it is insightful because it offers the subject, through the discovery of nation and race, an alternative to colonial discourse; it is shown to be limited because it is sentimental and intuitive and hence cannot be extended to other subjects. The narrator realizes that he cannot reproduce Trumper's "deepest instincts and emotions" or even his assurance. "I wasn't worried about my duty," says the narrator. "I had a lot of time to find what Trumper had already known, but a new thought had registered. Suppose I didn't find it. This was worse, the thought of being a part of what you could not become" (p. 299). Trumper offers possibilities of a new political awareness, but as Sandra Pouchet Paquet has observed in her reading of this scene, "This fear of being unable to meet the challenge of a black identity, this fear of incapacity, hangs ominously over the village community." 24

I want to argue that there is a narrative consequence to this psychological incapacity. Despite the different forms of dealing with language which we see exemplified by $G$ and Trumper, the splitting and dispersal of colonial subjects, rather than a resolution of their crisis of identity, is what initiates the autobiographical narrative and allows it to continue. So, on one hand, the act of narrating the self engenders the tracing of a process of separation and loss, but, on the other hand, the narrative foregrounds the utopian desire for isotopic integration. As in Lamming's other works, the shaping of narrative in The Castle is characterized by what Roland Barthes would call the dual power of narrativity - that of "distending its signs over the length of the story and that of inserting unforeseeable expansions into these distortions"; the 
function of narrative is to include the "deviations" it engenders within its own language. 25

We can see the kind of power Lamming bestows on the distorting capacity of his narrative even in the first pages of the novel. As I have already noted, the novel opens with doubts about origins and genealogy and with considerable hesitancy about the meaning of phenomena and G's relationship to his world. The authority of the narrative inheres in the exposition of the disjunctive function and displaced position of the narrating subject. As we have already seen, what was supposed to be an ideal scene of desire (a birthday) is dominated by figures and images that stress the contrary-crevices in the wall, flooded canals, and the weather that plays the child "false" (p. 9). Furthermore, the child narrator is attuned to absences or to reversals in conventional meanings: he rejects the mother's view of the floods as a blessing because in her interpretation there is no correspondence between signs and signifiers; instead he opts for the more apocalyptic reading of nature (of the floods as a curse) because this view allows for coherence between the image of nature he witnesses and his state of mind.

Thus as a narrator the boy must develop a rhetorical strategy that transcends his mother's religious symbols and repetitive tunes which have ossified into meaningless signs; he must also find a detour around her amnesia, which has blocked his memory and hence postponed any possible link with the missing past, in the same way the colonial school represses communal histories. Compelled to be a narrator in a social scene in which the self and its language are not authentic representations but the effects of others' desire, the boy must design a language of narrative built on a metonymic displacement of preexisting meanings. This process involves rejecting the integrative nature of narrative and seeking value in the fragmentary and parodic. More important, meanings are not the result of an original inquiry (although the boy desires this), but of repetition, itself an important feature of Lamming's text. Repetition is a strategy not only in those sections of the book which are narrated by the author (in which it serves a parodic function); it is also pronounced in the chapters the boy narrates.

Here we need to pose an elementary question: why does the subject

25. Roland Barthes, "Introduction to the Structural Analysis of Narratives," in A Barthes Reader, ed. Susan Sontag (New York: Hill and Wang, 1982), p. 288. 
prefer a strategy (repetition) that seems to retard the movement of the narrative, to hold back temporal development, which in the traditional bildungsroman is the movement toward knowledge and closure? Repetition, it must be stressed, is not the narrator's original strategy of dealing with his crisis of representation; rather, it mirrors the temporal situation in the village. In chapter 2, for example, the women tell the story of the floods over and over again: "They sat in a circle composed and relaxed, rehearsing, each in turn, the tale of dereliction told a thousand times during the past week" (p. 24). Repetition has become one way of controlling events and managing representation: the flow in the history of the floods, notes the boy, has acquired a pattern that "was undisturbed by any difference in the pieces, nor was its evenness affected by any likeness. There was a difference and there was no difference" (p. 25). The boy would rather have a strategy that moves him toward real difference, as Trumper's discourse at the end of the novel promises to do, but the fact that immediate history can be deprived of its referential status and then be retold as if there was "no difference" is a mark of the extent to which rewriting can confer authority on the already known, the already written. For the poor village people, stories retold acquire the authority of legends.

Lamming seeks the same kind of authority in his deliberate dispersal, distortion, and irradiation of narrative units. These examples of what Barthes, among other theorists of narrative, has called "dystaxia"-which occurs "when the signs (of a message) are no longer simply juxtaposed, when the (logical) linearity is disturbed"26_occur frequently in Lamming's narratives, but nowhere as prominently as in chapter 3 of The Castle. There the author presents a series of lexical units which mirror what he considers to be the contradictory impulses of narrative form. The first fragment of the chapter opens with what seems to be an authoritative description of the colonial school. But what appears, on one level, to be an objective representation is subtly undermined by qualifiers: the pebbled area "was called the school yard"; the church "seemed three times the size of the school"; the school was "supposed to be of Anglican persuasion" (p. 35). To the extent that this kind of representation foregrounds the narrator's hesitancy, rather than his authority, we may conclude that what we have here is indirect focalization in which a phenomenon is reflected through the boy's consciousness. But then how do we explain the 
obviously ironic conclusion to this lexia-the description of the school, the church, and the head teacher's house as "three shrines of enlightenment that looked over the wall and across a benighted wooden tenantry" (p. 35)? Are these the words of the child or the adult narrator?

Lamming's narrative strategy here is predicated on a deliberate confusion of the identity of the speaking subject. Indeed, in the second fragment of the chapter, where the school system is burlesqued (pp. 36-37), the speaking subject has been erased and the narrative becomes detached and impersonal as the narrator reflects on the equally fetishized symbols of colonial authority: "There were small flags and big flags, round flags and square flags, flags with sticks and flags without sticks, and flags that wore the faces of kings and princes, ships, thrones and empires" (p. 36). If the narrator cannot be depended on to produce determinate meanings, then language itself must be reinvented to become the source of value. But because the language spoken in the world of this novel, and the language the author uses, are colonial languages, they cannot be affirmed as they are; the ironic battery of language becomes the source of oppositional value. By the time the "red, white, and blue" colors of the flag have been repeated several times, Lamming has reduced the authoritative figures of empire to la bêtise. ${ }^{27}$

However, this emptying of the colonial language of its content and meaning cannot in itself provide an oppositional perspective. In another fragment, the boys struggle to produce an alternative view of things using dialogue and speech (rather than the formulas and clichés used in the school), but their discourse skids about aimlessly, seeking - but not quite finding - a center of authority. Significantly, this discourse (pp. 43-58) is both about issues of paternal and maternal authority and about the economy of representation in general: can colonial symbols be appropriated by the colonized and be reproduced? The boys take out the coins given to them at the school parade and "speculated whether it was possible to reproduce them, and made various attempts to represent them in pencil drawings" (p. 52). What is the value of this reproduced fetish, this illusion of an illusion? Can the boys ever have access to their original experiences? At the end of the

27. On the uses of irony and la bêtise as a discursive and narrative strategy, see Jonathan Culler, Flaubert: The Uses of Uncertainty (Ithaca: Cornell University Press, 1974), pp. 185-206, and Richard Terdiman, Discourse/Counter-Discourse: The Theory and Practice of Symbolic Resistance in Nineteenth-Century France (Ithaca: Cornell University Press, 1985), pp. 202-4. 
discourse, the boys can only conclude that the figure of the king on the coin, the figure that authorizes the value of the pennies, is just a shadow: "The shadow king was a part of the English tradition" (p. 55).

At the end of this chapter, the distinction between the boys and their teachers, as narrators, is collapsed: both groups are unable to narrate their way out of the closed world of the fetish and the cliché (pp. 7475). By the end of the novel, we have heard a multiplicity of voices and experienced several modes of focalization: we have listened to G's version of things, to the head teacher's interior monologue, and to Pa's ritualized forms of history (chapter 10); we have even read sections of G's diary (chapter 14). But we are never assured by the presence of a narrator who can pull all these experiences together. Is this then a narrative of dispersal, without a focalizing center? Whichever angle we choose to enter the narrative, things are never going to be tidy; Lamming's basic assumption is that the tension between the self and "the logical succession of events" (p. $x$ ) is what necessitates narrative. In this case, the narrative of assemblage is one in which the writer "takes historical moments and historical institutions and shifts them about to create one's mosaic." 28 Similarly, Lamming resists narrative closure because the narrative of history which his novels activate is continuous and open-ended; in this kind of narrative, he says, "there is really no closing of the drama. This experience will be a creative legacy, the soil of some other movement in life." 29 However, each of Lamming's subsequent novels takes up the issues of displacement and exile, nationalism and identity, dramatized in his first novel.

\section{Empire, Exile, and Narration: The Emigrants}

Our inevitable failure to grasp concrete meanings in Lamming's open-ended narratives has not always been accepted as the creative legacy he would like it to be. For although such texts have often promised to provide the reader with a thorough investigation of the colonial condition, they are notorious for rejecting ideological closure and providing indeterminate meanings. In other cases, readers have felt that Lamming's concern with narrative strategies and language has been too abstract and has not always provided the reader with a

28. George Kent, "Caribbean Novelist," Black World 22 (March 1973), 14.

29. Kent, p. 88. 
concrete knowledge of the Caribbean historical experience. This complaint is encapsulated in a review of Season of Adventure written by the Jamaican novelist Garth St Omer. According to St Omer, Lamming's narrative is destroyed by its "burden of knowledge and analogy"; the author's ideological allegiances "intrude in the world of the novel" at the expense of the historical situation and character; and his "indirect manner of narration does not make the book any easier to read. Again and again the reader is required to make inferences, draw conclusions from a narrative that seems intended more to surprise than to reveal and expose." 30

St Omer's criticism is heard often from readers encountering their first Lamming text, but the challenge these texts pose should not to be construed as a failing in narrative strategies, but as an inevitable consequence of the themes of alienation and displacement and linguistic incapacity which recur as his characters struggle for knowledge against the pressures of colonial domination. Like these imprisoned colonial subjects, the reader has to struggle to recuperate Lamming's meanings because his narratives are predicated on the traditional uncertainty of modernism and modernity: the author knows how to subvert the old, but not how to will the New Country-what Wilde calls the "socially, politically, and psychologically unified realm" - into being. ${ }^{31}$ Moreover, the narration of the political and psychological transition from colonialism to national independence cannot be posited as the replacement of one set of values with another, or as the simple recovery of previously repressed individual and communal desires. As Lamming tells George Kent, "Just because the so-called colonial situation and its institutions may have been transferred into something else, it is a fallacy to think that the human-lived content of those situations are automatically transferred into something else, too." The colonial experience is a psychic process that has to be dealt with "long after the actual colonial situation formally 'ends.' "32

In the absence of a clear transition from the colonial to the postcolonial value system, Lamming would agree with Gilles Deleuze and Félix Guattari that the (colonized) unconscious "poses no problem of meaning, solely problems of use. The question posed by desire is not 'What does it mean?' but rather 'How does it work?'." 33 Lamming's

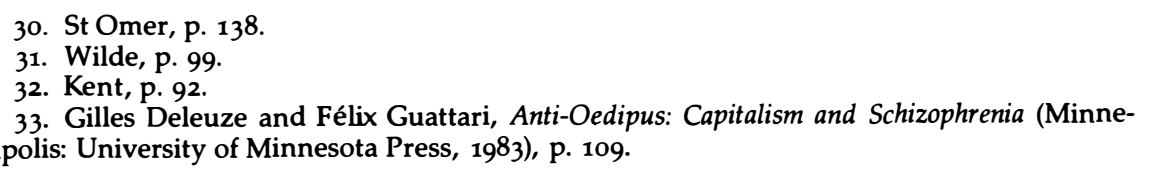


primary concern is how the trajectory of the colonial subject is retarded by the colonized unconscious and the problems of language and action it poses. For this reason, as we see very clearly in his second novel, The Emigrants, Lamming has adopted narrative strategies that emphasize displacement, discontinuity, and fragmentation. In the "space of uncertainty" created by these narrative modes of ironic distancing, Lamming seeks to signify the ultimate repression of the colonial subject and its failure to find representation in the colonial space. ${ }^{34}$ Moreover, the journey the emigrants undertake from their Caribbean islands to England is intended to function as a metaphor of the ultimate quest for the fantasy of empire-the colonized peoples go to the mother country to fulfill the identity promised by their education and acculturation. In the process of narration, however, and through the experience of exile, these subjects can relate to the metropolis only in terms of displacement and denial; the "mother" country becomes the ironic confirmation of previous states of fragmentation and failure which they had thought to escape by going abroad. ${ }^{35}$

Toward the end of The Castle, the narrator informed us that he was haunted by the thought "of being a part of what you could not become"; in The Emigrants, narration is predicated on the actualization of this fear. Indeed, what strikes us most about the emigrants' journey to the colonial metropolis, which is the central theme in this novel, is how often they are pushed into processes of self-alienation so that their life stories can be narrated, and how often reality takes on the power of spectacle and hence distances the subjects not only from their immediate experiences but also from the objects of their desires. Thus in the port city that constitutes the beginning of the emigrants' voyage, the first person narrator presents us with an image of "home" as a wild site of alienated desires; the Caribbean city can only be represented as a strange spectacle, even a nightmare: "The city was like a circus that had made its residence permanent beside the sea. The passengers couldn't believe it. Compared to what they had known or seen in Trinidad and Barbados this spectacle was wildly fascinating; a flame held in the hand, charged with the color and spark of fire, but unconsuming." 36 In this landscape, we don't find the kind of grasping

34. See Culler, p. 206.

35. See Pouchet Paquet, pp. 30-36. Ngugi wa Thiong'o has argued that the loneliness of the individual and his or her awareness of exile are not enough-"For Lamming a sense of exile must lead to action, and through action to identity" (p. 142).

36. George Lamming, The Emigrants (London: Allison and Busby, 1980), p. 10. Further references are in the text. 
for coherent meanings we saw in The Castle; on the contrary, the speaking subject has given in to his imagination; his representations have become projections of his neurosis, of his fear of the historical referent, of the past from which he is trying to escape, and of the future that awaits him. Rather than clarifying the status of the self, narration only provides the space in which the narrator can project himself into a world of shifting and unseen forms. This world, which appears as an imaginary gulf or valley, signifies the gap that stands between the narrator and the metropolis- "the thing beyond, which had its own secret of attraction and persuasion. A secret that urged identity" (p. 12).

Furthermore, the narrating subject delights in his capacity to represent himself in invented language as a way of creating the impression that he has mastered the "secrets of my identity" (p. 12). There is no longer the secret hankering for a natural ("agrarian") language that might help the self discover a phenomenal world. In fact, the linguistic spectacles this narrator creates around himself are marks of individual and social division and separation; the narrator displaces himself in the language he uses in such a way that the reader is no longer sure when and where to make the distinction between fact and fantasy, between experience and invention. In truth, Lamming presents us with a world in which representation has been emptied of significant meanings. For example, at the end of a long discourse on Good Friday in Guadeloupe, after an avalanche of phrases and descriptions with no relationship to any referent, the narrator is forced to question his own notions of reality-"suddenly it was no longer Good Friday and we might not have been at Guadeloupe" (p. 23). Even when the speaker poses as an authoritative source, his linguistic excesses force us to question his motives and the resulting "meanings." If the narrative impasse in The Castle is caused by a stammer, here it is caused by what the narrator calls "fluency."

Interestingly, the consequences of this fluency are not very different from the linguistic stammers we saw in Lamming's first novel. The first person narrator in The Emigrants uses a language that flows well but has little depth; this language is hence incapable of generating any authoritative meanings. To compensate for this lack of authority, Lamming shifts his focus from the "omniscient" narrator to a group of characters who represent a multiplicity of perspectives and can ostensibly provide the reader with a different path to reality and the truth amid the schizophrenia engendered by exile. Nevertheless, these 
characters are also entrapped by their own illusions and desires. Because they are victims of the language they have fashioned to express a false sense of self, or to deflate selfhoods that don't seem to live up to the images promoted by the empire, these subjects cannot represent external phenomena or themselves outside the paradigms delimited by their own fears, neuroses, and desires (see, for example, pp. 3334). As a result, the reader has no access to an original experience in which the self has primacy over the language it uses; indeed, we are caught in a hermeneutical tug-of-war between a self groping to understand its existential situation and a world of forms beyond the control of this subject.

But the tension between the self and predetermined forms is central to Lamming's analysis of the colonial situation. In one of his earliest essays reflecting on the identity of the black writer in a colonial situation, Lamming had argued that the Afro-Caribbean writer already encountered predetermined categories and definitions which he or she carried "like a limb":

A Negro writer is a writer who, through a process of social and historical accidents, encounters himself, so to speak, in a category of men called Negro. He carries this definition like a limb. It travels with him as a necessary guide for the Other's regard. It has settled upon him with an almost natural finality, until he has become it. He is a reluctant part of the conspiracy which identifies him with that condition which the Other has created for them both. He does not emerge as an existence which must be confronted as an unknown dimension; for he is not simply there. $\mathrm{He}$ is there in a certain way. ${ }^{37}$

Lamming's basic assumption that the black self encounters a predetermined identity against which it must struggle if it is to "touch" its true consciousness affects representative strategies in The Emigrants. Identity in this novel is determined not only by the inevitable tension between self and other, as they both seek "the unknown dimension" that might point the way out of the mutual prison of imposed identities, but also by their urgent quest for a point of interpretation beyond given meanings.

Unfortunately, says Lamming, selves with imposed identities are victimized by "a state of surprise and embarrassment" which leads to shame, "the shame that touches every consciousness which feels that 
it has been seen." 38 For example, early in the emigrants' voyage Collis tries to become acquainted with Dickson in a bid to penetrate the psychological defenses the latter has built around himself. Almost subliminally, however, the tension that defines the relationship between self and other is foregrounded-Collis becomes a threat to Dickson by his very presence. But since this threat is not based on any tangible action (it is really a reflection of the sense of insecurity which all the colonized share, in particular the fear of being seen or known), there is no way any mode of reconciliation between the two can be effected. Indeed, Collis's attempts to overcome the "suspicion in Dickson's knowledge" lead to a fight (p. 35). The situation is further complicated by the fact that there is nothing Collis can do to explain or rationalize the situation: "To say that he had asked a simple question of the man, was refused an answer, felt he had offended and tried to apologise: that would have made no sense" (p. 35).

The point Lamming is making here is simple: in a world in which relationships have broken down and neurosis has nullified meanings, representation can no longer appeal to the authority of the speaking subject nor can narrative be predicated on the subject's ability to interpret its conditions of existence. Here Lamming's narrative project is closer to that of the late modernists: his characters have no access to, nor do they strive for, phenomenological meanings as they did in The Castle. These are the kind of characters who inhabit the late modernist texts of the 1950s, characters removed from reality and confined by what Alan Wilde aptly calls "a sort of cultural or psychological dyslexia, which blurs vision itself." 39 To recognize the importance Lamming attaches to this failure of vision, we have to remember that The Emigrants is cast in a structural mode that is essentially ironic. The voyage motif that underlies the novel's structure promises coherence and discernible meanings at the end of the process; as we have already seen; colonized subjects believe that the metropolis is the site in which they can engender themselves. As the novel progresses, however, it becomes apparent that the voyage frustrates the characters' quest for intelligibility and identity; the closer to its destination the ship moves, the more difficult it becomes for the subjects to organize their experiences in order to make sense out of them.

The voyagers assume that the journey is a mechanism for overcom-

38. Lamming, "The Negro Writer and His World," p. 109.

39. Wilde, p. 109. 
ing the gap between their Caribbean reality and metropolitan desire, and for reuniting the sign (the idea of the mother country) and the signifier (the real England). Of the voyagers, we are told, "no one knew the place they were going to, but everyone talked about the place he was leaving" (p. 52); and yet the more they hear about experiences of life in England, as related to them by those who have previously lived in that country (Tornando and the Governor), the more they are forced to reconsider the terms of their interpretation. They see the paradox that underlies their experience: "We others don't know the place and yet we're anxious to arrive" (p. 52); "perhaps we were all living without looking" (p. 53).

The basic problem confronting both the subject and the reader of Lamming's text can be reduced to a simple interpretative question: how do we make sense of a world of fetishized illusions? Or as Jonathan Culler has observed in terms of the semiotics of the novel as a mode of representation, "How are they to organize and relate to this strange world? What sort of connection can be made between the inner and outer, between the psychological drama and the historical and political circumstances?" 40 For Lamming, the world of the emigrant is already estranged and estranging; it is made up of people "who always saw their fulfillment elsewhere, outside of the society." 41 Represented by the other through the fetishistic symbols of empire we saw parodied in The Castle, the colonized live in a world that shrouds and embalms them in the very mythologies from which they thought they were escaping. In The Emigrants, Lamming is seeking narrative strategies the colonial writer can use to reproduce the colonial mentality, to show how it begins to disintegrate as it encounters the metropolis, and to indicate how this disintegration raises the possibility of a Pan-Caribbean identity. ${ }^{42}$

Indeed, as the encounter between the Caribbean emigrants and England draws closer, the main characters in the novel shift from their previous concerns with self-engenderment and begin reflecting on the possibilities of penetrating the ideological veil that conceals their real relationship with the colonizer. Their quest now is not for objects of vague desire awaiting them at the other side of the gulf, but for rules of understanding, a grid in which knowledge of the other can be transformed so that the self can touch its consciousness. Narration thus

40. Culler, p. 213.

41. Kent, p. 95.

42. Pouchet Paquet, p. 32. 
becomes the movement toward a decolonized point of interpretation; as one of the emigrants puts it aptly, "The Interpretation me give hist'ry is people the world over always searchin' an' feelin', from time immemorial, them keep searchin' an' feeling" (p. 68). The interpretation of history and the historicization of interpretation form one way of countering the mythology of empire.

Once the necessity of historicization has been established, the narratives of emigration are no longer replays of colonial fantasies; in the new slave ship and reversed "middle passage," the emigrants seek ways of evolving a counter-narrative of empire. Now the emigrants reflect on the possibility of negating the narrative of empire by embracing the popular forms of Caribbean culture, forms they might previously have seen as causes of shame and embarrassment. Such popular forms are important because they challenge the very foundations of Eurocentric cultural codes and suggest an alternative hermeneutics. Thus, the calypso dance in the middle of part 1 prefigures a world in which the body is the source of its own designs, of "its own logic of receptivity and transmission, a world that could be defined only through the presence of others, yet remained in its definition absolute, free, itself. The body was part of the source of its being and at the same time its being" (p. 94). Figuratively, the Caribbean body becomes a space free of a contaminating foreign culture. At the same time, however, the overwhelming reality-the cause of anxiety and uncertainty-for the emigrants is that their identities are still fixed by the colonizer and their experiences are still mediated by the discourse of empire. Thus the desire to rediscover Caribbean popular culture comes up against the powerful machinery of empire, setting off numerous contradictions that destabilize the self. As the ship approaches the dock in England, the emigrants see the deck "hidden under a black lack of cause or choice, a veiled contradiction that would only receive some arbitrary meaning from an imaginative presence" (p. 95). So the quest for a counter-narrative is, paradoxically, underwritten by a pronounced modernist angst.

Nevertheless, the narrative seeks to negotiate the emigrants' desire to recover an autonomous but denigrated form (the calypso) and to recenter it in the "imaginative" presence of empire, which has hitherto defined them as a people without a culture. In a curious way, however, the emigrants' response to the crisis of what Lamming calls vision presents a problem - for narration to proceed, the self must be erased as a source of meaning and significance. In the case of the calypso, the 
body can only maintain its integrity in its biological form; because calypso is not authorized by colonial culture, the bodies it proffers are not recognized by the other, and in its function as a desiring machine, the body in the calypso dance does not seem to have cultural meaning. Indeed, its freedom depends on "the physical discharge of itself" which "constituted an open secret which everyone saw but could not read"; in showing itself, the body is "exhausted and broken by its own desire" (p. 94). But if the body yields to the presence of empire and gives in to the delirium of the other which it cannot grasp nor represent, it is hence nullified (pp. 118-24). In both cases, the self exists only as a phantasm, as what psychologists J. Laplanche and J. B. Pontalis define as "an imaginary scene in which the subject is a protagonist, representing the fulfillment of a wish . . . in a manner that is distorted." 43

For Lamming, though, it is this erasure of the colonial self which generates a narrative that in turn inscribes the contradictory and reified site in which the colonial subject is produced. As he observes in "The Negro Writer and His World," to speak about the situation of the black writer and of the writer in general, within the "contemporary situation which surrounds men with an urgency that is probably unprecedented," is to speak of "the universal sense of separation and abandonment, frustration and loss, and above all, of man's direct inner experience of something missing." 44 The centering of absence here is a significant shift in Lamming's response to the key and inescapable problem of representing the colonial subject. For if narration in The Castle was shown to be impossible unless its author confronted the issue of subjectivity and the place of the speaking subject in the narrative, now the absence of the subject is the key to writing about exile and alienation.

We have a good example of how absences determine the nature of a narrative in the second part of The Emigrants: here the story centers around neither the self nor its other, but is generated by a hiatus between the two entities. This hiatus is manifested by the failure of the colonizer and the colonized to initiate the dialogue that Lamming had earlier hoped could reconstitute the relationship between Prospero and Caliban. Brought together by historical necessity or accident, the

43. J. Laplanche and J. B. Pontalis, The Language of Psycho-Analysis, trans. Donald Micholson-Smith (London: Hogarth Press, 1973), p. 314.

44. Lamming, "The Negro Writer and His World," pp. 110-11. 
Englishman Pearson and the Trinidadian Collis are confronted by the gulf between them and discover the need for silence where there should have been dialogue: "It seemed right that there should be silence" (p. 144). Even among the emigrants themselves, speech is no longer spontaneous and they often resort to linguistic masks to conceal the self not only from the other, but also from itself. Repression of selfhood has become the condition of exile. Whereas they were earlier associated with regional pride and "national" (or island) traits, and with a determination to assert their distinctive cultural and social identities, the emigrants have now become substitutable; the reader no longer bothers to tell the difference between them because they seem to have little individual identity.

Even the significance of the metropolis, initially conceived as the source of the emigrant's identity, has been deprived of its cultural and psychological value- "England was simply a world which we had moved about at random, and on occasion encountered by chance" (p. 229). The function of narrative, it would seem, is to sustain displacement because this is the reality of the colonial condition. Lamming does not present displacement as an end in itself, however; instead, it is posited as a prelude to the characters' need to eventually reinvent themselves in their quest for a more meaningful identity. For example, once in England Una Solomon can kill her former self, Queenie, and acquire a new identity; "it didn't matter" who she was now "because I didn't really belong to it" (p. 239). However, this kind of self-alienation is motivated by what Lamming has identified as a greater utopian desire-"the desire for totality, a desire to deal effectively with that gap, that distance which separates one [person] from another, and also in the cause of an acute reflective self-consciousness, separates [people] from [themselves]." 45 The gap between the nationalist desire for totality and the nightmare of colonial history is the subject of Of Age and Innocence.

\section{The Drama of Politics: Of Age and Innocence}

In discussing the relationship "of the artist to the drama of politics" as a basic theme in his works, Lamming has been keenly aware of the special difficulties confronting writers who are products "of a society

45. Lamming, "The Negro Writer and His World," p. 112. 
in a state of transition and which is at the same time an explosive society." 46 Fictions that offer blueprints for national formation, or seek to realize the desire for national consciousness in narrative terms, often have to contend with two basic historical problems: (1) the nationalist movement draws its strength from its basic opposition to colonialism, but it does not yet have a language to harmonize the disparate elements that constitute the emerging nation; (2) political developments in the postcolonial situation seem to indicate that the new nations in the Caribbean replay the errors of colonial history anew. ${ }^{47}$ Lamming's political narratives are hence informed by a paradox: they seek to will a new Caribbean nation into being, but they also deconstruct the premises of nationalism, especially its dependence on the matrix of modernization. As he told George Kent, Of Age and Innocence presents the society in The Castle "now extended to the whole area in its last stages of colonialism." 48 This extension has important ideological and narratorial implications.

In her incisive critique of the narratives of national formation in the so-called Third World, Jean Franco has explored this paradox in terms I find pertinent to the politics and poetics of Lamming's novel. According to Franco, the narratives of national formation, especially those written during the period of transition from colonialism to national independence, are propelled by the writer's inability to sustain the illusion of the new nation as a harmonization of national ideals. Unable to will the new nation into being, writers of such narratives proffer "a skeptical reconstruction of past errors" and try to make "visible that absence of any signified that could correspond to the nation." These novels enact "a motley space in which different historical developments and different cultures overlap" and dramatize "the unfinished and impossible project of the modernizing state." 49 Now, the target of Lamming's criticism is not merely the colonizer, but those Caribbean politicians and activists who, in seeking to nationalize, and hence appropriate, the colonizing structures forget to tap the roots of West Indian culture to create a more harmonious culture. At the dawn of independence, the differences nationalists had repressed in order to

46. Ian Munro and Reinhard Sander, eds., Kas Kas: Interviews with Three Caribbean Writers in Texas: George Lamming, C. L. R. James, Wilson Harris (Austin: African and Afro-American Research Institute, 1972), p. 12.

47. I borrow this phrase from Jean Franco, "The Nation as Imagined Community," in The New Historicism, ed. H. Aram Veeser (New York: Routledge, 1989), p. 205.

48. Kent, p. 96.

49. Franco, p. 205. 
present a common front against the colonizer begin to emerge and threaten the new nation. In the process of narrating the problems of the emerging nation, Lamming's novel marks the dissolution of what Franco would call the once totalizing myth of the nation "which is now replaced by private fantasies lived out amid public disaster. And the novel, rather than an allegory, has become the terrain of conflicting discourses." 50

Lamming expresses this theme of the failure of the nationalist quest for a totalizing narrative and the ascendancy of conflicting discourses in several ways: by constantly representing a triple discursive conflict between what the narrative enacts, what characters assumed were original experiences, and the popular meaning of such experiences; and by expressing recurrent stammers in the linguistic structures his characters formulate in their often futile attempts to create a singular meaning for the nation. These stammers call our attention to the absence of a signified that might correspond to the nationalists' dream of liberation. Indeed, both strategies coalesce in the struggle between "things" and "words" which marks most of the novel. For example, at the beginning of the novel, as the plane carrying the emigrants returning home to San Cristobal prepares to land, Mark "could not receive what his eyes were seeing"; the pages of his diary-a document intended by its very generic configuration to capture authentic experience-remained "a familiar contrivance of words and paper which ignored all desire." 51 Because Mark is returning to his native land at the end of the colonial era as a witness to both the death of colonialism and the birth of an independent Caribbean nation, words are an important instrument for rewriting the history of the country and the self. Such an act of rewriting, as I have argued earlier, is one way of overcoming the anxieties of exile. For if Mark, who has no prior knowledge of his native island except what he has read in books, can represent his people directly_that is, without mediating them through the values and concepts previously set by the colonizer-then he can generate a narrative of the nation in which public and private histories can be harmonized. Indeed, Mark's ultimate desire is to legitimize the new nation, and his place in it, through narrative.

But as Mark writes, he finds that words will not simply function as

50. Franco, p. 208.

51. George Lamming, Of Age and Innocence (London: Allison and Busby, 1981), p. 11. Further references are in the text. 
signs of his desires; the old language refuses to be mastered by his will, and the production of a new idiom faces numerous obstacles. His struggle to capture his experiences in writing foregrounds the "absence of things outside; and that absence, transparent and impenetrable had taken meaning from his mind" (p. 14). The same linguistic blockage affects other characters in the novel. For example, when Mark's wife, Marcia, tries to "collect" words in her head as a way of dealing with a situation of crisis (the possible crash of the plane), she realizes that words don't provide the clarity and coherence she needs; rather, they are "vague and vagrant," resisting the command of her desires, refusing "to obey their normal use." The words "slipped from their meaning, sailing briefly like feeble noises that stumble for a while before returning to the silence which contains them. The signs did not cohere. The ends would not meet in a meaning which would help her memory" (p. 13).

What these examples illustrate is a situation already hinted at in Lamming's earlier texts-attempts to capture the self and its historical conditions in writing inevitably lead to self-alienation, and it is this alienation that ignites and fires Lamming's narrative. In Of Age and Innocence, the subjects' quest for elusive meanings dramatically foregrounds the close link between language and the crisis of identity Lamming has isolated as one of the key issues in the colonial situation. In his many discussions of linguistic practice under colonialism, Lamming has argued that his primary desire is a form of rational language which the colonial subject can command. He has categorically stated that language, for colonized peoples, functions as "symbolic interpretation," as an "instrument of the exploring consciousness." 52 But to trace this language of interpretation-to read Lamming through his discourse on language, writing, and reading -is to fall into what Louis Althusser once called "the mirror myth of knowledge as the vision of a given object or the reading of a given text."53 Even a critic like Pouchet Paquet, possibly the most insightful reader of Lamming's novels, falls into the trap of transparency when she says that in Of Age and Innocence, "Lamming offers a detailed social analysis based on the specific relationships between representative, and therefore typical, characters, and between these characters and their environment." 54

52. Kent, p. 88.

53. Louis Althusser and Etienne Balibar, Reading Capital, trans. Ben Brewster (London: Verson, 1970), p. 19.

54. Pouchet Paquet, p. 64. 
Lamming may certainly desire such a close correspondence between subject and history in his discourses on reading and writing, but my contention is that narration in his third novel is predicated on the impossibility of such a relationship. In multifarious ways, the novel invites a reading that traces the dislocation inscribed in its narrative and linguistic structures, a dislocation that is the most manifest symptom of the division between the dream of the nation and its realities. On the most elementary level, this dislocation is obvious in the subjects' anxiety about their selfhood and capacity to represent themselves in language or even to communicate their intentions. Thus Marcia knows why she and Mark are leaving England for the Caribbean, but she cannot verbalize this reason: "She understood only for herself; she could not communicate what she understood, just as the dialogue she had read was at once final and incomplete" (p. 35). Mark's diary-which she had assumed would contain the motives for his decision to return to the Caribbean-only complicates the process of understanding; "it seemed the diaries followed no regular order in time" (p. 36). Even Penelope's decision to leave England "existed without reference to any logic of thinking or feeling" (p. 41).

Lamming's characters hence function in a world in which words float around without referents. Clearly, the new nation does not provide a cultural or political project these characters can identify with; at the moment of independence, characters still experience what Lamming considers to be a dislocation of facts, historical sense, and meanings. Nationalism was supposed to lead to the rehabilitation of the nation through the revalorization of its history and the reinstitution of its national culture. But in Lamming's deconstructive moments, the circumstances in which the new nation emerges (according to Lamming, "the tactical withdrawal which the British now proudly call decolonization simply made way for a new colonial orchestration" [The Castle, p. xiv]) have led to the disappearance of the nation-state as a valid framework for a new Caribbean identity. ${ }^{55}$

Nowhere is the disappearance of the nation as a framework for coherent meanings as clearly demonstrated as in the "mad" discourse of the nationalist, Shepherd. Here we have a discourse of the unconscious which in the end functions as a mirror image of the historical displacement of the island of San Cristobal, its reduction to an unknown and unformed place of conflict and struggle. According to Shepherd: 
You do not know San Cristobal, coming up by accident one morning from water, the tiny skull of a mountain top which was once asleep under the sea. Here Africa and India shake hands with China, and Europe wrinkles like a brow begging every face to promise love. The past is all suspicion, now is an argument that will not end, and tomorrow for San Cristobal, tomorrow is like the air in your hand. I know San Cristobal. It is mine, me, divided in a harmony that still pursues all its separate parts. No new country, but an old land inhabiting new forms of men who can never resurrect their roots and do not know their nature. [P. 58]

Unlike Mark, a returned exile seeking validation through a national allegory in which everything is knowable and representable through harmonizing national symbols, Shepherd sees the island as a reflection of himself, divided and alienated from its roots and traditions. Shepherd's alienation in language, and his separation from nature and culture, allow Lamming to make visible the vestiges of colonialism in the Caribbean nation about to be born.

In significant ways, then, Lamming's novel confronts the issue of representation on a more problematic level than the symbolic one that Pouchet Paquet's reading promotes. Lamming's premise is that the novel, as a document legitimizing the claims of the new nation, is the medium through which-in Fanon's apt phrase- "the Past is given back its value." 56 But for this past to be revalorized in a new national narrative, the writer must bring together the scattered elements of ethnic (or national) history and give it a new meaning against a colonial mentality trained to resist anything that comes from Africa or Asia. The paradox of the new national culture, as Shepherd notes in the above quotation, is that the new inhabitants of a territory constructed by the colonizer cannot fully resurrect their old roots nor completely recover their precolonial nature.

In writing on the colonized intellectual's "passionate search for a national culture which existed before the colonial era," Fanon argues that this quest is motivated by the anxiety to "shrink away from that Western culture in which they risk being swamped." "Because they realize they are in danger of losing their lives and thus becoming lost to their people," says Fanon, these men, hotheaded and with anger in their hearts, relentlessly determine to renew contact once more with the oldest and most pre-colonial springs of life of their people." 57 As

56. Frantz Fanon, The Wretched of the Earth, trans. Constance Farrington (New York: Grove Press, 1968), p. 211.

57. Fanon, pp. 209-10. 
Shepherd suggests in his speech, the same kind of romantic anxiety engenders Mark's discourse of return. This discourse is limited because it isolates the speaker from a past that is contentious and contested and more complex than it appears, because it fails to come to terms with linguistic and cultural differences, and because it seeks old forms to express new social constructs. Indeed, if the problem of representing history "is essentially a narrative problem, a question of the adequacy of any storytelling framework in which History might be represented," as Fredric Jameson has argued in another context, 58 Lamming's narrative takes up a similar problem: Can the history of an emerging Caribbean nation ever find an adequate framework? Can an old land inhabited by new people use old forms to express its resurrected history, or was Fanon right in saying that "the crystallization of the national consciousness will both disrupt literary styles and also create a completely new public"?59

The innate limitation of old ossified forms is exposed in Shepherd's mother's folktale version of the island's history. In her story, Ma Shepherd inscribes her authority by appealing to nature and tradition and by trying to transcend her temporal limitations: her claim is that the measure of time is "too great" to be restrictive. Her version of events will be authoritative not only because she witnessed some of them (the fire and the floods), but also because by destroying "paper, an' records men make for rememberin'," these natural disasters left her memory as the only record of the past (p. 67). It is noteworthy, however, that history appears to the old woman not as a process but as a spectacle, the projection of her own fears, her apocalyptic vision and apprehension of the world. Thus her historical "revelations" are steadily questioned by the rest of the narrative, and when she becomes the key state witness in the trial of nationalists arrested for sedition, then her "historical" discourse is shown to be compromised. But if we cannot trust Ma Shepherd's recollection and representation of history through old forms, neither can we trust the official version. The history of San Cristobal appears "broken" to Penelope because she cannot find documents to verify local legends (pp. 87-88), but the reader is already aware that even if such documents existed, they could only denote a partial and ideologically slanted view of the island. Does this mean that the history of this Caribbean island has been destroyed beyond

58. Fredric Jameson, The Political Unconscious: Narrative as a Socially Symbolic Act (Ithaca: Cornell University Press, 1981), p. 49.

59. Fanon, pp. 239-40. 
recovery? Can narrative recover a history that has no documents or reliable memories?

Lamming suggests that there are two possible narrative ways of reconstructing history: we can excavate fragments and ruins from the past and strive to fill the gaps in existing local histories, thereby establishing vital connections; or we can valorize the gaps and fragments of this history and turn them into actual sources of imaginary value. Both alternatives come into play in clearly connected ways. Mark, for example, believes that historical gaps can be plastered by privatizing history, appealing to the power of the individual experience, so to speak. His diaries are hence textual instruments for transforming absences and gaps into meanings that originate in the self. When he tries to describe an ordinary scene, Mark notices an absence of relationships between the resulting discourse and its objects; but he says that it is "precisely this absence which seems to restore each thing to its completeness. A certain lack of connection had endowed the pebble with a formidable and determined power of its presence. It was there, independent, obstinate, decisive" (p. 72). Indeed, Mark is no longer worried about his inability to recover his authentic self from the debris of Caribbean history. Instead, he adopts his failure to recover an essentialist experience as the source of the authority of his discourse. Unable to embark on an archeological quest for the past and recover some truth from what he aptly calls "the dreary pile of history," he notes that although what he sought was the "original" version of things, he is condemned to repetition: "Each account can only be a fresh corpse which we assemble in order to dissect again. Nothing was lost when I burnt the last pages of the pirate's biography. I had only burnt a little corpse whose original I could never know" (p. 107).

But the central problem of Caribbean modernism, as we have already seen, has to do with fear toward, and confusion about, beginnings. Lamming's novel poses a simple question in this regard: where does colonialism end and where does the postcolonial situation begin? Indeed, what is the decolonized subject's point of entry into Caribbean history? Addressing a nationalist crowd at a political meeting, Mark chooses the legend of the Tribe Boys as his point of entry into what he hopes is a rational dialogue between himself and the people of San Cristobal, but in the end his speech becomes "a fragment of a monologue between Mark Kennedy and himself, and the theme was his identity" (p. 179). At the end of the novel, the three boys who have become symbolic embodiments of the island's main ethnic groups 
have committed themselves to defend nationalism, to rise in revolt like "the Tribe Boys do," but their resistance is just a repetition of the past, not a new beginning: "It was a moment which entered them like steel, one accident of time exploding from the whole accumulated muddle of their past. It opened the earth under their feet to honour their fantasy and their hope" (p. 412).

Lamming, then, seems to express doubts about those attempts at new beginnings in the Caribbean which confuse the new with the original: what is original in the Caribbean, what begins with the "discovery," which I have been using as the inaugural moment of Caribbean modernism, can never be an ideal beginning; it is rather like that corpse Mark Kennedy dissects every time he tries to recover the origins of his pirate subject. And so modernity, and the discourse on national identity which it nurtures, still remain incomplete projects in Lamming's early works, to be taken up in his later novels, in the works of his contemporaries Samuel Selvon, Alejo Carpentier, and Paule Marshall, and in those of a younger generation of Caribbean writers such as Merle Hodge, Zee Edgell, and Michelle Cliff. 